\title{
DRY MATTER PRODUCTION AND NUTRIENT ACCUMULATION AFTER SUCCESSIVE CROPS OF LETTUCE, TOMATO, RICE, AND ANDROPOGON- GRASS IN A SUBSTRATE WITH ZEOLITE ${ }^{(1)}$
}

\author{
Alberto C. de Campos Bernardi ${ }^{(2)}$, Marisa Bezerra de Mello Monte ${ }^{(3)}$, \\ Paulo Renato Perdigão Paiva ${ }^{(3)}$, Carlos Guarino Werneck ${ }^{(4)}$, Patrick \\ Gesualdi Haim $^{(4)} \&$ Fernando de Souza Barros ${ }^{(5)}$
}

\begin{abstract}
SUMMARY
Zeolites are hydrated crystalline aluminosilicate minerals of natural occurrence, structured in rigid third dimension net that can be used as slow release plant-nutrient source. The main objective of this study was to evaluate the effects of plant growth substrate under zeolite application, enriched with $\mathrm{N}, \mathrm{P}$ and $\mathrm{K}$, on dry matter yield and on nutrient contents in consecutive crops of lettuce, tomato, rice, and andropogon grass. The experiment was carried out in a greenhouse, with $3 \mathrm{~kg}$ pots with an inert substrate, evaluated in a randomized block design with three replications. Treatments consisted of four types of enrichment of concentrated natural zeolite: concentrated zeolite $(\mathrm{Z})$ only, zeolite $+\mathrm{KNO}_{3}(\mathrm{ZNK})$, zeolite $+\mathrm{K}_{2} \mathrm{HPO}_{4}(\mathrm{ZPK})$ and zeolite $+\mathrm{H}_{3} \mathrm{PO}_{4}+$ apatite $(\mathrm{ZP})$, and a control grown in substrate fertilized with a zeolite-free nutrient solution. Four levels of enriched zeolite were tested: $20,40,80$, and 160 g/pot. Four successive crops were grown on the same substrate in each pot: lettuce, tomato, rice, and andropogon grass. Results indicated that $\mathrm{N}, \mathrm{P}$ and $\mathrm{K}$ enriched zeolite was an adequate slow-release nutrient source for plants. The total dry matter production of above-ground biomass of four successive crops followed a descending order: $\mathrm{ZP}>\mathrm{ZPK}>\mathrm{ZNK}>\mathrm{Z}$.
\end{abstract}

Index terms: stilbite, Lactuca sativa, Lycopersicum esculentum, Oryza sativa, Andropogon gayanus, slow-release fertilizer, growth substrate.

\footnotetext{
(1) Recebido para publicação em maio de 2009 e aprovado em novembro de 2009.

(2) Pesquisador, Embrapa Pecuária Sudeste. Rod. Washington Luiz, km 234, Caixa Postal 339, CEP 13560-970 São Carlos (SP). Email: alberto@cppse.embrapa.br

${ }^{(3)}$ Pesquisador, Laboratório de Química de Superfície - Centro de Tecnologias Minerais - CETEM. Rio de Janeiro (RJ). E-mails: mmonte@cetem.gov.br; ppaiva@cetem.gov.br

(4) Pós-Graduando, Universidade Federal Rural do Rio de Janeiro - UFRRJ. Seropédica (RJ). E-mails: cgwerneck@yahoo.com.br; patrickhaim@yahoo.com

(5) Professor Emérito, Instituto de Física, UFRJ, Rio de Janeiro (RJ). E-mail: fsbarros@if.ufrj.br
} 


\title{
RESUMO: PRODUÇÃO DE MATÉRIA SECA E ACÚMULO DE NUTRIENTES APÓS CULTIVOS SUCESSIVOS COMALFACE, TOMATE, ARROZ E CAPIM ANDROPOGON EM SUBSTRATO COM ZEÓLITA
}

\begin{abstract}
Zeólitas são minerais aluminossilicatos cristalinos hidratados de ocorrência natural, estruturados em redes cristalinas tridimensionais rígidas que podem ser usados como fonte de liberação lenta de nutrientes para as plantas. O objetivo deste trabalho foi avaliar o efeito da adição de zeólita enriquecida com N, P e Kao substrato de cultivo sobre a produção de matéria seca e o acúmulo de nutrientes pelas culturas sucessivas de alface, de tomate, de arroz e de capim-andropogon. O experimento foi conduzido em vasos em casa de vegetação, em vasos contendo $3 \mathrm{~kg}$ de substrato inerte. O delineamento experimental foi o de blocos ao acaso, com três repetições. A zeólita natural estilbita foi concentrada e enriquecida com nutrientes $N, P e$ Kobtendo-se os seguintes tratamentos: zeólita concentrada (Z), zeólita $+\mathrm{KNO}_{3}(\mathrm{ZNK})$, zeólita $+\mathrm{K}_{2} \mathrm{HPO}_{4}(\mathrm{ZPK})$ e zeólita $+\mathrm{H}_{3} \mathrm{PO}_{4}+$ apatita $(\mathrm{ZP})$, além de um tratamento testemunha sem adição de zeólita, mas com solução nutritiva. Utilizaram-se quatro doses de zeólita enriquecida: 20, 40, 80 e 160 g/vaso. Foram realizados quatro cultivos sucessivos no mesmo substrato de cada vaso: alface, tomate, arroz e capim-andropogon. Os resultados indicaram que a zeólita enriquecida com N, Pe K funcionou como fonte de nutrientes de liberação lenta. A produção de matéria seca total da parte aérea dos quatro cultivos sucessivos seguiu a seguinte ordem decrescente: $Z P>Z P K>Z N K>Z$.
\end{abstract}

Termos de indexação: estilbita, Lactuca sativa, Lycopersicum esculentum, Oryza sativa, Andropogon gayanus, fertilizante de liberação lenta, substrato de cultivo.

\section{INTRODUCTION}

Zeolite minerals are hydrated aluminosilicates of alkali or alkaline-earth metals, structured in a threedimensional rigid crystalline network, formed by tetrahedral $\mathrm{AlO}_{4}$ and $\mathrm{SiO}_{4}$, whose rings join in a system of canals, cavities and pores. These minerals are characterized by the ease of retaining and releasing water and exchanging cations without structural changes (Mumpton, 1999; Kithome et al., 1999) and can potentially be used in field or substrate cultivation (Harland et al., 1999). There are over 40 species of natural zeolites, of which clinoptilolite is apparently the most abundant, both in soils and in sediments (Ming \& Dixon, 1987). In Brazil, the largest zeolite reservoirs are found in the Parnaíba river valley (Rezende \& Angélica, 1991), where the stilbite form of the heulandite group predominates (Monte et al., 2009).

Three of the main properties of these naturally occurring minerals are of great interest for agricultural purposes: high cation exchange capacity, high water holding capacity in the free channels, and high adsorption capacity.

Zeolites improve nutrient use efficiency by increasing $\mathrm{P}$ availability from phosphate rocks, improving the use of $\mathrm{NH}_{4}{ }^{+}-\mathrm{N}$ and $\mathrm{NO}_{3}{ }^{-}-\mathrm{N}$, reducing leaching losses of exchangeable cations, especially $\mathrm{K}^{+}$, and also acting as slow-release fertilizer (Barbarick et al., 1990; Notario-Del-Pino et al., 1994; Allen et al., 1995; Williams \& Nelson, 1997; Harland et al., 1999; Pickering et al., 2002; Gül et al., 2005; Bernardi et al., 2008). According to Leggo (2000), due to the high affinity of zeolites for nutrients, these minerals may be used in growth media to improve plant yields. Mixtures of zeolite and fertilizers also had positive effects on lettuce (Gül et al., 2005) and tomato yields (Valente et al., 1986). In addition, zeolites improve efficiency of water use, by increasing soil water holding capacity and water availability to plants (Xiubin \& Zhanbin, 2001; Bernardi et al., 2009).

The main objective of this study was to evaluate effects of zeolite addition, enriched with N, P and K, to the plant growth substrate on dry matter yield and on nutrient contents by consecutive crops of lettuce, tomato, rice and andropogon grass.

\section{MATERIAL AND METHODS}

The experiment was carried out in greenhouse, in $3 \mathrm{~kg}$ pots with inert substrate of sand washed with distilled water and diluted $\mathrm{HCl}$ solution $\left(3: 1 \mathrm{v} \mathrm{v}^{-1}\right)$. Zeolite was collected in the state of Maranhão, Brazil, in the Parnaiba river basin (Rezende \& Angélica, 1991). According to the procedure described by Monte et al. (2009), the raw material was homogenized, split, crushed, and sieved. Contaminants (quartz and iron oxides and hydroxides) were separated from zeolite by gravitational concentration, using a Humphrey spiral. These procedures resulted in a material with $840 \mathrm{~g} \mathrm{~kg}^{-1}$ stilbite and cation exchange capacity of $2.5 \mathrm{cmol}_{\mathrm{c}} \mathrm{g}^{-1}$. The chemical formula of zeolite was determined as follows: $(\mathrm{CaO})_{0,82}\left(\mathrm{Na}_{2} \mathrm{O}\right)_{0,19}\left(\mathrm{~K}_{2} \mathrm{O}\right)_{0,15}$ $(\mathrm{MgO})_{0,56}\left(\mathrm{Fe}_{2} \mathrm{O}_{3}\right)_{0,30}\left(\mathrm{TiO}_{2}\right)_{0,11}\left(\mathrm{Al}_{2} \mathrm{O}_{3}\right)_{1,85}\left(\mathrm{SiO}_{2}\right)_{16}$ $\left(\mathrm{H}_{2} \mathrm{O}\right)_{4,7}$. Concentrated zeolite ( $\mathrm{Z}$ ) was dispersed in a 
solution containing $0.5 \mathrm{~mol} \mathrm{~L}^{-1} \mathrm{NaCl}$, at a weight:volume proportion of 1:10 to saturate negative charges with $\mathrm{Na}^{+}$. Suspensions were stirred for $24 \mathrm{~h}$ at room temperature, centrifuged, filtered and dried at $100{ }^{\circ} \mathrm{C}$. The homoionic material was dispersed again in solutions containing $1.0 \mathrm{~mol} \mathrm{~L}^{-1} \mathrm{H}_{3} \mathrm{PO}_{4}(\mathrm{ZP})$, $0.5 \mathrm{~mol} \mathrm{~L}^{-1} \mathrm{KNO}_{3}(\mathrm{ZNK})$ or $1.0 \mathrm{~mol} \mathrm{~L}^{-1} \mathrm{~K}_{2} \mathrm{HPO}_{4}(\mathrm{ZPK})$ at a weight proportion of $1: 40$, and these solutions were stirred for $24 \mathrm{~h}$ at room temperature, centrifuged, filtered and dried at $100^{\circ} \mathrm{C}$. Zeolite enriched with $\mathrm{H}_{3} \mathrm{PO}_{4}$ was also mixed with phosphate rock (apatite - $340 \mathrm{~g} \mathrm{~kg}^{-1} \mathrm{P}_{2} \mathrm{O}_{5}$ ), at a weight proportion of 1:10 $\left(\mathrm{g} \mathrm{g}^{-1}\right)$. The following $\mathrm{N}, \mathrm{P}$ and $\mathrm{K}$ concentrations were determined in the saturation paste extract of the substrate (Embrapa, 1997): $\mathrm{N}$ and $\mathrm{K}$ in ZNK treatment, 21,180 and $15,210 \mathrm{mg} \mathrm{kg}^{-1}$, respectively; $\mathrm{P}$ and $\mathrm{K}$ in $\mathrm{ZPK}$ treatment, 11,289 and $41,925 \mathrm{mg} \mathrm{kg}^{-1}$, respectively; and $\mathrm{P}$ in $\mathrm{ZP}$ mixture, $7,130 \mathrm{mg} \mathrm{kg}^{-1}$.

Treatments consisted of four levels of each enriched zeolite mixture: $20,40,80$, and $160 \mathrm{~g} / \mathrm{pot}$ and a control (without application of concentrated zeolite). The control was nurtured with all essential elements in solution as follows $\left(\mathrm{mg} \mathrm{L}^{-1}\right): \mathrm{N}=210 ; \mathrm{P}=31 ; \mathrm{K}=234$; $\mathrm{Ca}=200 ; \mathrm{Mg}=48 ; \mathrm{S}=65 ; \mathrm{B}=0.5 ; \mathrm{Cu}=0.02 ; \mathrm{Fe}=$ $5.0 ; \mathrm{Mn}=0.5 ; \mathrm{Zn}=0.2$, and $\mathrm{Mo}=0.02$ (Sarruge, 1975). Nutrient solutions were supplied at $100 \mathrm{~mL}$ per pot in all cultivation cycles every three days in the first 30 days of cultivation, and thereafter every day. Plants were watered on the days when no nutrient solution was supplied. Nutrient solution composition varied according to treatments, and the nutrients absent in the enriched zeolites were supplied by a nutrient solution at the same concentration as the control. This ensured the supply of all treatments at the same quantities of $\mathrm{Ca}, \mathrm{Mg}, \mathrm{S}, \mathrm{B}, \mathrm{Cu}, \mathrm{Fe}, \mathrm{Mn}$, Mo, and Zn.

The experiment was arranged in a completely randomized block design with three replications. Four sucessive crops were grown on the same substrate: lettuce (Lactuca sativa L. cv. Regina), tomato (Lycopersicum esculentum Mill. cv. Finestra), rice (Oryza sativa cv. Soberana), and andropogon grass (Andropogon gayanus cv. Baeti). Nursery plants of lettuce, tomato, rice, and andropogon grass were transplanted to pots 30 days after germination. Lettuce, tomato and rice plants were harvested, respectively, after 30, 60 and 90 days of growth. Andropogon grass was cut twice, after 60 days and after 45 days of regrowth. Aboveground biomass was sampled, dried at $65{ }^{\circ} \mathrm{C}$ for $72 \mathrm{~h}$ for dry matter determination and ground in a Wiley mill with a 20 mesh sieve. Nitrogen, $\mathrm{P}$ and $\mathrm{K}$ levels were evaluated in the aboveground biomass according to the porcedure of Carmo et al. (2000). The $\mathrm{N}$ levels was determined in sulphuric extract by the semimicro-Kjeldahl method. Phosphorus and K levels were determined in nitric perchloric extract, respectively, by inductively coupled plasma optical emission spectrometry and flame spectrometry. After each harvest, a $50 \mathrm{~g}$ sample of the growth substrate was collected to analyze the saturation paste extract of the substrate (Embrapa, 1997), in which $\mathrm{N}$ and $\mathrm{K}$ of the ZNK treatment, $\mathrm{P}$ and $\mathrm{K}$ of $\mathrm{ZPK}$ and $\mathrm{P}$ of the $\mathrm{ZP}$ treatment were determined.

Data were tested for differences among treatments using analysis of variance. Equations were adjusted as a function of treatments.

\section{RESULTS AND DISCUSSION}

Lettuce dry matter (DM) yields were highest under applications of 13 and $9.9 \mathrm{~g} /$ pot of zeolite enriched with $\mathrm{H}_{3} \mathrm{PO}_{4}+$ apatite (ZP) and $\mathrm{KNO}_{3}(\mathrm{ZNK})$, respectively, at levels of 51.1 and $89.1 \mathrm{~g} /$ pot (Figure 1a). Based on the DM yield of the control of $9.7 \mathrm{~g} / \mathrm{pot}$, the best treatment (ZP) resulted in increases of $34 \%$ of lettuce DM yield, as similalry observed by Gül et al. (2005). There was an inverse relationship with zeolite + $\mathrm{K}_{2} \mathrm{HPO}_{4}$ supply (ZNK), probably due to $\mathrm{NaCl}$ residues used during the material treatment. Cramer \& Spurr (1986) reported deleterious effects of salt stress on lettuce plants, leading to a biomass decline with increasing salinity, both during the initial growth and the production phase. In this first crop a quadratic response to the supply of non-enriched zeolite was also observed, unlike in the subsequent crops, indicating a probable anion retention in the exchange complex of the mineral.

The ZP and ZPK zeolites induced the highest tomato DM yield (70.8 and $65.7 \mathrm{~g} / \mathrm{pot}$ ), with doses of 126.5 and $115.3 \mathrm{~g} /$ pot (Figure $1 \mathrm{~b})$. These yields were, respectively, $50.3 \%$ and $39.5 \%$ higher than of the control (47.1 g/pot). The greatest DM yield in the ZNK treatment $(25.8 \mathrm{~g} / \mathrm{pot})$ was obtained at the highest rate (160 g/pot). Nanadal et al. (1998) also found tomato increased yields with the improvement of $\mathrm{P}$ and $\mathrm{K}$ availability in the substrate. The DM percentage increase in lettuce and tomato cultivation was higher than reported by Leggo (2000), who compared substrate-grown plants under zeolite application and observed a $19 \%$ DM increase when zeolite was present.

A marked DM yield decrease was observed for the third crop, rice (Figure 1c), when treated with zeolite enriched with $\mathrm{P}, \mathrm{P}$ and $\mathrm{K}$, and $\mathrm{N}$ and $\mathrm{K}$, since these treatments achieved lower values than the control mean $(46.5 \mathrm{~g})$. The average DM yield under pure zeolite (40.2 g) application was equal to the two previous crops. In the third crop, yields obtained with ZNK treatment were very low and did not differ from each other, confirming the depletion of $\mathrm{N}$ and $\mathrm{K}$ sources.

The average DM yield of the above-ground biomass of andropogon grass indicated the same trend for the first and second cut (Figure 1d). Control and concentrated zeolite achieved the best results due to the replacement of nutrients taken up by harvested 


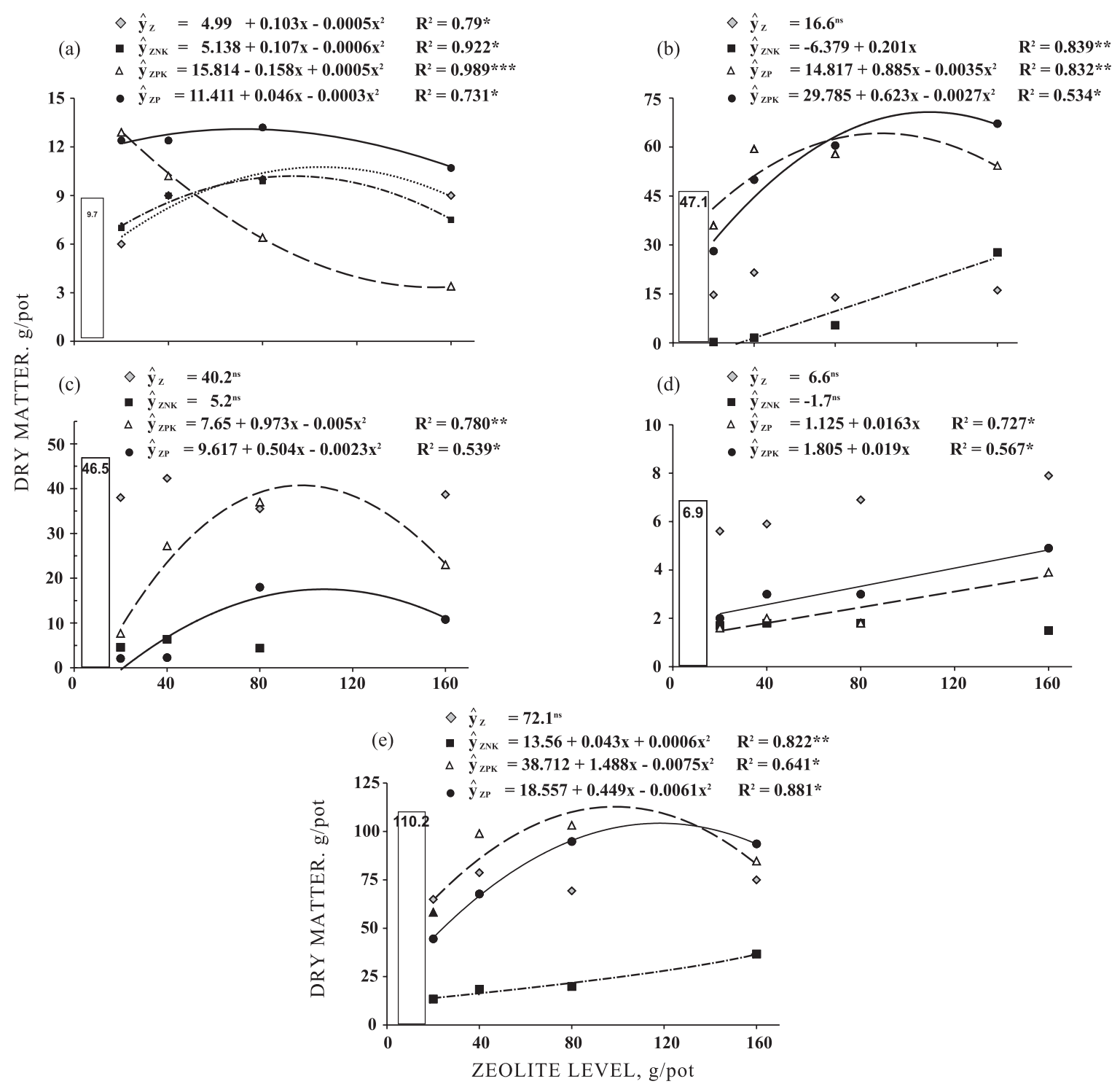

Figure 1. Dry matter yield of lettuce (a), tomato (b), rice (c) and andropogon grass (two cuts - d) and total (e) of plants grown in zeolite-enriched $(\mathrm{Z})$ substrate enriched with $\mathrm{N}, \mathrm{P}$ and $\mathrm{K}$. The bar indicates the control mean (without zeolite).

plants. The treatment with $\mathrm{N}$ and $\mathrm{K}$ resulted in a lower DM yield, while the ZP treatment obtained equal yields as the most soluble $\mathrm{P}$ source $\left(\mathrm{K}_{2} \mathrm{HPO}_{4}\right)$ (Figure 1a,d). Thus, results indicate the potential use of ZP treatment as slow-release fertilizer. These results are consistent with those obtained by Allen et al. (1995), who concluded that the mixture of clinoptilolite and phosphate rock from North Carolina, at a ratio of $5: 1\left(\mathrm{w} \mathrm{w}^{-1}\right)$ was efficient for intensive cultivation of wheat (Tritticum aestivum cv. Coker). Barbarick et al. (1990) also found that the combination of zeolite and phosphate rock can be an efficient $\mathrm{P}$ supplier to plants, as long as the other elements are not limiting. The dynamic equilibrium between zeolite and apatite, which provides $\mathrm{P}$ source dissolution and $\mathrm{P}$ release, were also observed and discussed by Lai \& Eberl (1986).
Since sequential extractions were performed, results indicated that the doses of enriched zeolite required for maximum productivity tended to be higher in the last than the first crop. The DM production of the best treatments at the beginning of the crop succession declined gradually, due to nutrient depletion in the culture substrate.

With regard to $\mathrm{N}$ uptake (Figure $2 \mathrm{a}$ ), the highest values in $\mathrm{ZP}, \mathrm{ZPK}$ and $\mathrm{ZNK}$ treatments were obtained with doses of $111.3,160.0$ and $146.2 \mathrm{mg} / \mathrm{pot}$, respectively. Maximum absorption of $630.5 \mathrm{mg} \mathrm{N}$, obtained at the inflection point of the response curve, represented $20.4 \%$ of the available nutrient concentration.

Total $\mathrm{P}$ amounts extracted by the above-ground biomass of lettuce, tomato, rice, and andropogon grass 
(Figure 2b) of ZPK or ZP treatments were higher than those of the control. Maximum extraction of 322.9 and $271.4 \mathrm{mg}$ of $\mathrm{P}$ were obtained with 129 and $160 \mathrm{~g}$ zeolite, respectively. In relation to the initially available macronutrient amounts, 22.2 and $23.8 \%$ of total $\mathrm{P}$ were extracted by the aboveground biomass of the four crops.

Figure 4 shows the high $\mathrm{P}$ availability in the substrate treated with zeolite-enriched apatite. Notario-Del-Pino et al. (1994) compared P and K supply (as $\mathrm{K}_{2} \mathrm{HPO}_{4}$ ) through zeolite (phillipsite) in a greenhouse experiment with alfalfa, and confirmed increased levels of these nutrients in plants after
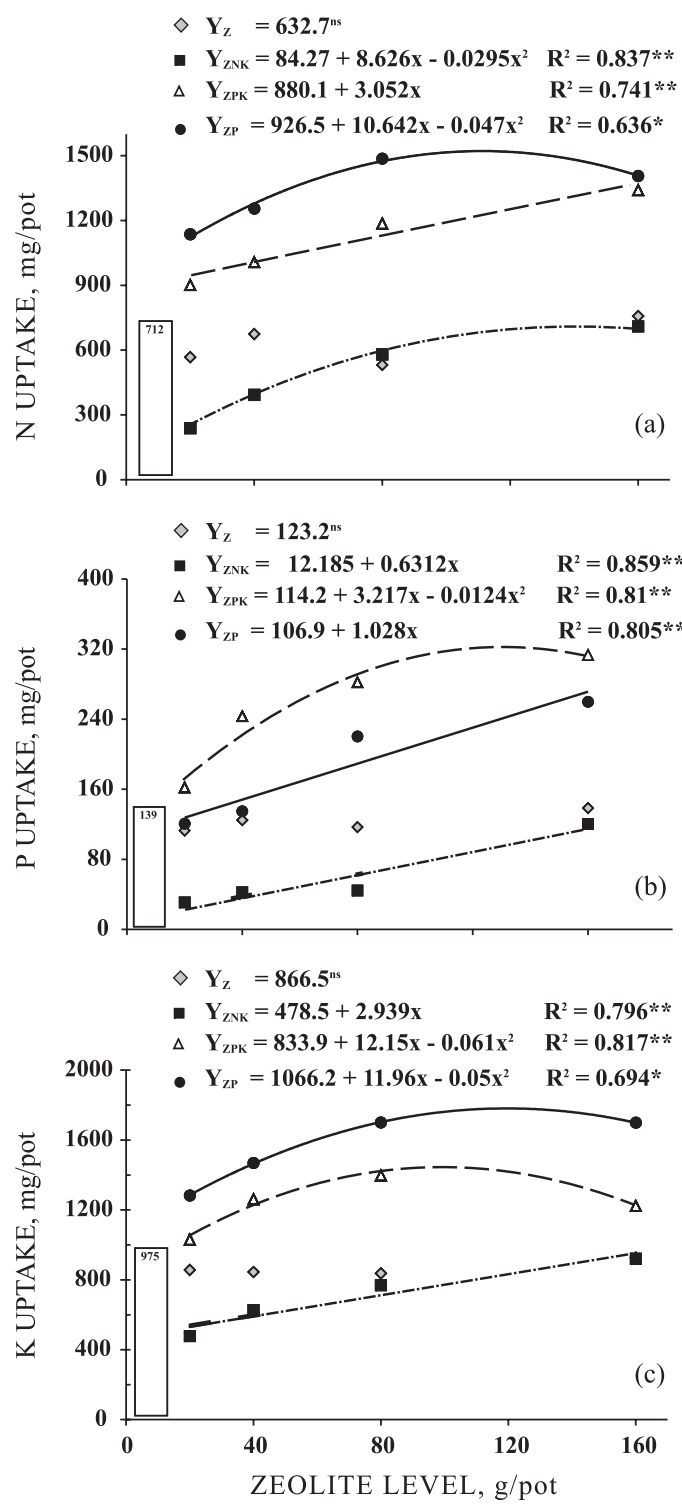

Figure 2. Nitrogen (a), phosphorus (b) and potassium (c) uptake in aboveground biomass of lettuce, tomato, rice, and andropogon grass (two cuts) plants successively grown in zeolite-enriched substrate zeolite - enriched with $\mathrm{N}, \mathrm{P}$ and $\mathrm{K}$. The bar indicates the control mean. increase of mineral levels. Pickering et al. (2002) also observed an increase in $\mathrm{P}$ uptake in sunflower plants grown in substrate enriched with zeolite mixed with phosphate rock.

The results of this study indicated that K extraction (Figure 2c) followed the same trend as observed for the other two analyzed nutrients ( $\mathrm{N}$ and $\mathrm{P}$ ), due to the strong influence of this element on DM production. Thus, the greatest K accumulations (1781, 1441 and $949 \mathrm{mg}$ ) were obtained with doses of $119.6,99.9$ and $160 \mathrm{~g}$ of $\mathrm{ZP}, \mathrm{ZPK}$ and $\mathrm{ZNK}$, respectively. In the $\mathrm{ZP}$ treatment extraction by the above-ground biomass was generally highest, due to the higher dry matter yield. The K amounts extracted in ZPK and ZNK treatments, which were enriched with this macronutrient, accounted for $34.4 \%$ and $38.9 \%$ of the total initially available K, respectively. These results were similar to those of Williams \& Nelson (1997), who observed a considerable increase in $K$ extracted by chrysanthemum over the control, which was treated with nutrients in solution form only. However, the K amount extracted here was greater than found by Gruener et al. (2007), who observed that the zeoliteenriched substrate still contained $52 \%$ of $\mathrm{NH}_{4}{ }^{+}-\mathrm{N}$ and $78 \%$ of the original $\mathrm{K}$ in the mineral exchange complex after three successive radish crops. This concentration also exceeded that reported for wheat growth on a zeolite-enriched substrate in which approximately $80 \%$ of $\mathrm{NH}_{4}{ }^{+}-\mathrm{N}$ and $\mathrm{K}$ remained in the exchange complex after harvesting (Lai \& Eberl, 1986).

The nutrient supply capacity of the substrate can be assessed by estimating the nutrient availability in a saturation extract solution. This method simulates the growing conditions best and allows the determination of readily available nutrients for plants (Ende, 1989; Sonneveld et al., 1990). With regard to changes in $\mathrm{N}$ levels (as nitrate) and $\mathrm{K}$ of the ZNK treatment, there was the same trend of yield decrease in the crop succession (Figure 3a,b). Nitrogen and K reduction after tomato cultivation was very intense, indicating the high $\mathrm{N}$ and $\mathrm{K}$ demand of this species.

A reversal in the downward trend of $\mathrm{P}$ and $\mathrm{K}$ levels, respectively, was observed after lettuce under ZPK (Figures 3c and 4a). This result confirms the earlier observation of reduced plant growth, leading also to a lower rate of nutrient uptake $(\mathrm{P}$ and $\mathrm{K})$ at the highest zeolite dose. In the following crop, tomato, the reduction of $\mathrm{P}$ and $\mathrm{K}$ levels followed the general trend.

The reduction of $\mathrm{P}$ availability in zeolite saturation extract of ZP treatment (Figure 4b) also shows the same trend observed in the other treatments. This once again suggests the possibility of an adequate supply of this essential element as a non-soluble source, as had been observed by Allen et al. (1995), Barbarick et al. (1990) and Lai \& Eberl (1986).

These results illustrate the nutrient depletion in the substrate and explain the earlier observation that the doses required for maximum productivity increased 


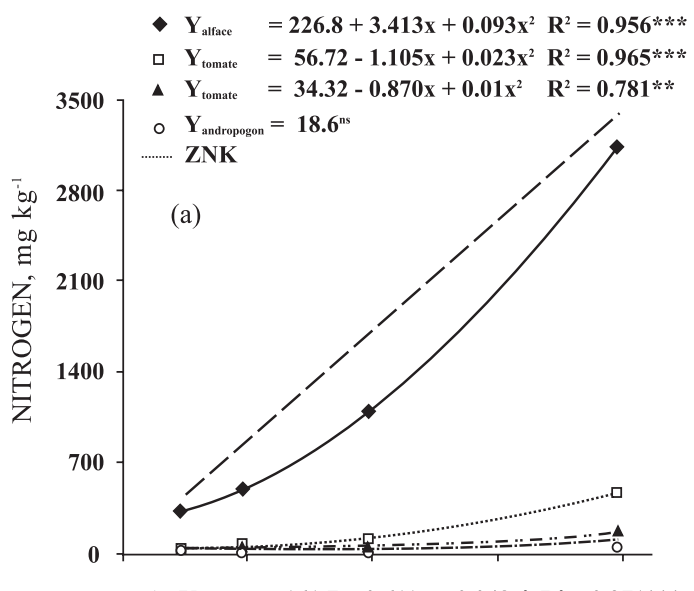

- $\mathrm{Y}_{\text {alface }}=161.7+0.611 \mathrm{x}+0.048 \mathrm{x}^{2} \mathbf{R}^{2}=0.971^{* * *}$

ㄷ $Y_{\text {tomate }}=101.5-1.815 x+0.029 x^{2} \quad R^{2}=0.964 * * *$

$\triangle Y_{\text {tomate }}=-40.248+1.752 x \quad R^{2}=0.912 * *$

○ $Y_{\text {andropogon }}=15.12+0.892 x \quad R^{2}=0.955^{* * *}$

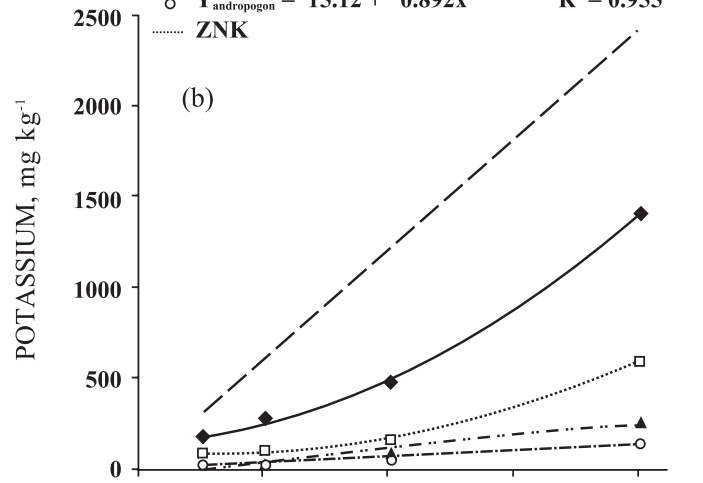

$Y_{\text {alface }}=-399.3+59.786 x-0.171 x^{2} R^{2}=0.967 * * *$

ㄷ $Y_{\text {tomate }}=-4.978+0.382 x+0.0129 x^{2} R^{2}=0.941 * * *$

$\triangle Y_{\text {tomate }}=38.89-1.547 x+0.018 x^{2} \quad R^{2}=0.844^{* *}$

ㅇ $Y_{\text {andropogon }}=10.42-0.752 x+0.01 x^{2} \quad R^{2}=0.973 * * *$

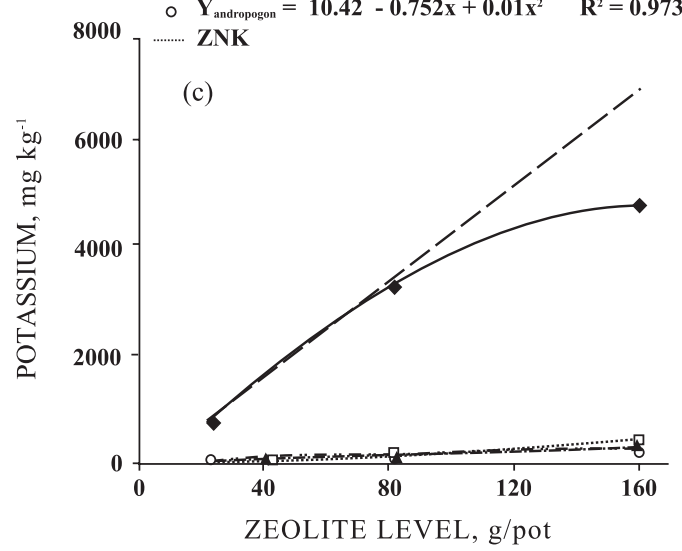

Figure 3. Nitrogen and $K$ levels in the treatment zeolite $+\mathrm{KNO}_{3}(\mathrm{ZNK}-\mathrm{a}$ and $\mathrm{b}), \mathrm{K}$ in the treatment zeolite $+\mathrm{K}_{2} \mathrm{HPO}_{4}(\mathrm{ZPK}-\mathrm{c})$ in the saturation paste extract of the substrate, after successive crops of lettuce, tomato, rice, and andropogon grass (two cuts). The dotted line indicates the level at the beginning of the experiment.

gradually with sequential crops (lettuce, tomato, rice, and andropogon grass). The potential use of zeolite as an adequate slow-release nutrient source for plants

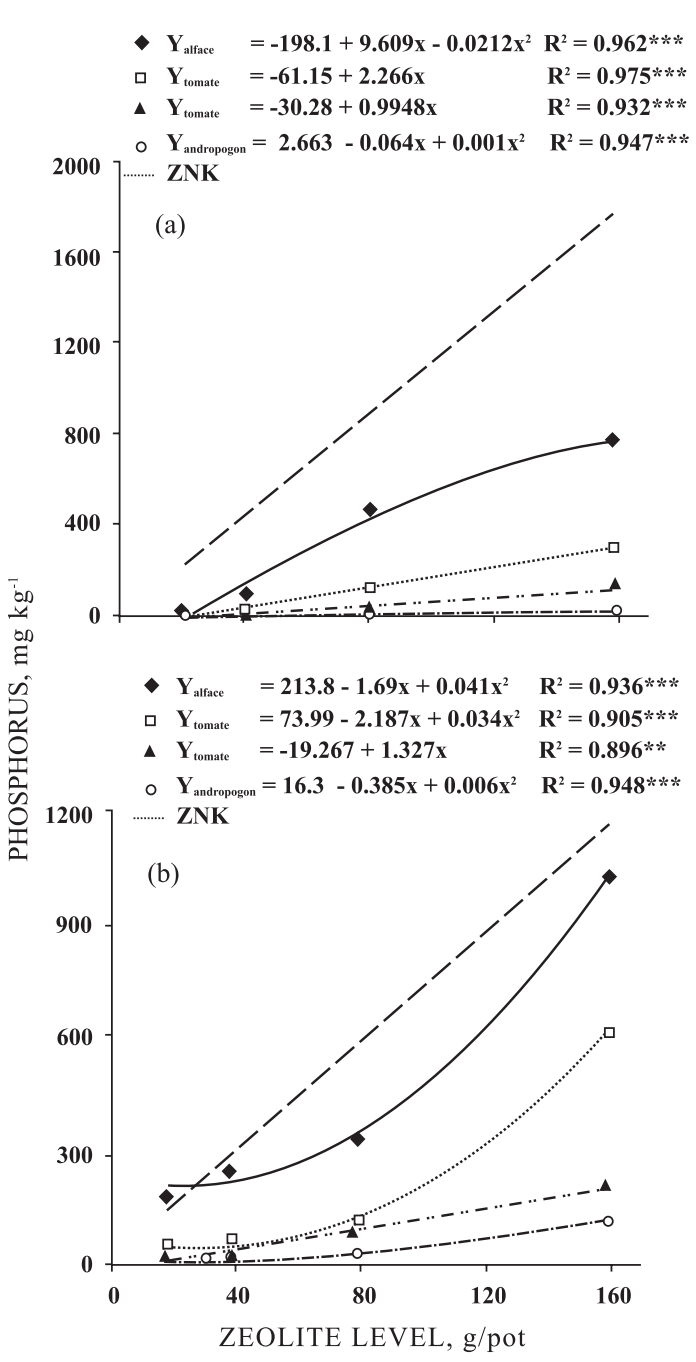

Figure 4. Phosphorus levels in the treatments zeolite $+\mathrm{K}_{2} \mathrm{HPO}_{4}(\mathrm{ZPK}-\mathrm{a})$ and zeolite $+\mathrm{H}_{3} \mathrm{PO}_{4}+$ apatite (ZP - b) in the saturation paste extract of the substrate, after successive crops of lettuce, tomato, rice, and andropogon grass (two cuts). The dotted line indicates the content at the beginning of the experiment.

could therefore be demonstrated. These results are in agreement with findings of Valente et al. (1986) for tomato, by Notary-Del-Pino et al. (1994) for alfalfa, by Allen et al. (1995) for wheat, by Williams \& Nelson (1997) for chrysanthemum, by Harland et al. (1999) for pepper, by Gül et al. (2005) for lettuce, by Gruener et al. (2007) for radish, and by Bernardi et al. (2008) for Rangpur lime rootstock.

\section{CONCLUSIONS}

Results indicated that N, P and K-enriched zeolite was an adequate slow-release nutrient source for plants. Production of total dry matter of above-ground 
biomass of four successive crops followed a decreasing order: zeolite $+\mathrm{K}_{2} \mathrm{HPO}_{4}>$ zeolite $+\mathrm{H}_{3} \mathrm{PO}_{4}+$ apatite $>$ zeolite $+\mathrm{KNO}_{3}>$ concentrated zeolite.

\section{ACKNOWLEDGEMENTS}

This research was supported by grants of the Brazilian National Council of Research and Development $(\mathrm{CNPq})$ and the Financiadora de Estudos e Projetos FINEP (Brazilian Agency of Research and Projects).

\section{LITERATURE CITED}

ALLEN, E.; MING, D.; HOSSNER, L.; HENNINGER, D. \& GALINDO, C. Growth and nutrient uptake of wheat in a clinoptilolite-phosphate rock substrate. Agron. J., 87:10521059, 1995.

BARBARICK, K.A.; LAI, T.M. \& EBERL, D.D. Exchange fertilizer (phosphate rock plus ammonium-zeolite) effects on sorghum-sudangrass. Soil Sci. Soc. Am. J., 54:911916, 1990.

BERNARDI, A.C.C.; WERNECK, C.G.; HAIM, P.G.; REZENDE, N.G.A.M.; PAIVA, P.R.P. \& MONTE, M.B.M. Crescimento e nutrição mineral do porta-enxerto limoeiro 'Cravo' cultivado em substrato com zeólita enriquecida com NPK. R. Bras. Frutic., 30:794-800, 2008.

BERNARDI, A.C.C.; MENDONÇA, F.C.; WERNECK, C.G.; HAIM, P.G. \& MONTE, M.B.M. Disponibilidade de água e produção de arroz em função das doses de concentrado zeolítico. Irriga, 14:123-134, 2009.

CARMO, C.A.F.S.; ARAÚJO, W.S.; BERNARDI, A.C.C. \& SALDANHA, M.S. Métodos de análise de tecidos vegetais utilizados na Embrapa Solos. Rio de Janeiro, Embrapa Solos, 2000. 41p. (Embrapa Solos. Circular Técnica, 6)

CRAMER, G.R. \& SPURR, A.S. Responses of lettuce to salinity. I. Effects of $\mathrm{NaCl}$ and $\mathrm{Na}_{2} \mathrm{SO}_{4}$ on growth. J. Plant Nutr., 9:115-130, 1986.

EMPRESA BRASILEIRA DE PESQUISA AGROPECUÁRIA EMBRAPA. Centro Nacional de Pesquisa de Solos. Manual de métodos de análise de solo. Rio de Janeiro, 1997. 212 p. (Embrapa-CNPS. Documentos, 1)

ENDE, J.van den. Estimating the chemical composition of the soil solution of glasshouse soil. 1. Compositions of soil solution and aqueous extracts. Nether. J. Agric. Sci., 37:311-322, 1989.

GRUENER, J.E.; MING, D.W.; GALINDO JR., C.; HENDERSON, K.E. \& GOLDEN, D.C. Plant productivity and characterization of zeoponic substrates after three successive crops of radish (Raphanus sativus L.). Microp. Mesop. Mater., 105:279-284, 2007.
GÜL, A.; EROGUL, D. \& ONGUN, A.R. Comparison of the use of zeolite and perlite as substrate for crisp-head lettuce. Sci. Hortic., 106:464-471, 2005.

HARLAND, J.; LANE, S. \& PRICE, D. Further experiences with recycled zeolite as a substrate for the sweet pepper crop. Acta Hortic., 481:187-194, 1999.

KITHOME, M.; PAUL, J.W.; LAVKULICH, L.M. \& BOMKE, A.A. Effect of $\mathrm{pH}$ on ammonium adsorption by natural zeolite clinoptilolite. Comm. Soil Sci. Plant Anal., 30:14171430, 1999.

LAI, T.M. \& EBERL, D.D. Controlled and renewable release of phosphorous in soils from mixtures of phosphate rock and $\mathrm{NH}_{4}$-exchanged clinoptilolite. Zeolites, 6:129-132, 1986.

LEGGO, P.J. An investigation of plant growth in an organozeolitic substrate and its ecological significance. Plant Soil, 219:135-146, 2000.

MING, D.W. \& DIXON, J.B. Quantitative determination of clinoptilolite in soils by a cation-exchange capacity method. Clays Clay Miner., 35:463-468, 1987.

MONTE, M.B.M.; MIDDEA, A.; PAIVA, P.R.P.; BERNARDI, A.C.C.; REZENDE, N.G.A.M.; BAPTISTA FILHO, M.; SILVA, M.G.; VARGAS, H.; AMORIM, H.S. \& SOUZABARROS, F. Nutrient release by a Brazilian sedimentary zeolite. An. Acad. Bras. Ci., 81:641-653, 2009.

MUMPTON, F.A. La roca magica: Uses of natural previous zeolites in agriculture and industry. Proc. Nat. Acad. Sci. United States America, 96:3463-3470, 1999.

NANADAL, J.K.; RAMESH, V. \& PANDEY, U.C. Effect of phosphorus and potassium on growth yield and quality of tomato. J. Potassium Res., 14:44-49, 1998.

NOTARIO-DEL-PINO, J.S.; ARTEAGA-PADRON, I.J.; GONZALEZ-MARTIN, M.M. \& GARCIA-HERNANDEZ, J.E. Response of alfalfa to a phillipsite-based slow-release fertilizer. Comm. Soil Sci. Plant Anal., 25:2231-2245, 1994.

PICKERING, H.W.; MENZIES, N.W. \& HUNTER, M.N. Zeolite/rock phosphate - a novel slow release phosphorus fertiliser for potted plant production. Sci. Hortic., 94:333343, 2002.

REZENDE, N.G.A.M. \& ANGÉLICA, R.S. Sedimentary zeolites in Brazil. Mineral. Petrogr. Acta, 42:71-82, 1991.

SARRUGE, J.R. Soluções nutritivas. Summa Phytopatol., 1:231-233, 1975.

SONNEVELD, C.; van den ENDE, J. \& BES, S.S. Estimating the chemical compositions of soil solutions by obtaining saturation extracts or specific 1:2 by volume extracts. Plant Soil, 122:169-175, 1990

VALENTE, S.; BURRIESCI, N.; CAVALlARO, S.; GALVAGNO, S. \& ZIPELLI, C. Utilization of zeolite as soil conditioner in tomato growing. Zeolites, 2:271-274, 1986. 
WILLIAMS, K.A. \& NELSON, P.V. Using precharged zeolite as a source of potassium and phosphate in a soilless container medium during potted chrysanthemum production. J. Am. Soc. Hortic. Sci., 122:703-708, 1997.
XIUBIN, H. \& ZHANBIN, H. Zeolite application for enhancing water infiltration and retention in loess soil. Res. Conserv. Recycl., 34:45-52, 2001. 